\title{
Clove Oil (Syzygium aromaticum) Edible Film Formulation and Antibacterial Activity Test against Streptococcus mutans
}

\author{
Wida Ningsih ${ }^{1 *}$, Afdhil Arel ${ }^{2}$
}

${ }^{1}$ Universitas Baiturrahmah, Jalan Raya By Pass, Aie Pacah, Koto Tangah, Aie Pacah, Kec. Koto Tangah, Kota Padang, Sumatera Barat 25586 2Universitas Muhammadiyah Sumatera Barat, Jl. Pasir Jambak No.4, Pasie Nan Tigo, Kec. Koto Tangah, Kota Padang, Sumatera Barat 25172

\section{Abstract}

Clove oil contains eugenol as an antibacterial. Meanwhile, products containing clove oil have been widely used as toothpaste and mouthwash. In this study, clove oil was formulated in the form of edible film because it is practical, easy to use, and could be used without water like other oral hygiene preparations. The edible film is a thin layer film made of consumable materials used as a carrier of antibacterial compounds. Clove oil edible film was then formulated with clove oil concentrations of $1 \%, 1.5 \%$, and $2 \%$ and determined for its antimicrobial activity against Streptococcus mutans. Clove oil edible film preparations were evaluated under their physical properties, including friability, drying shrinkage, $\mathrm{pH}$, thickness, and swelling ability. Antibacterial activity testing of clove oil edible film was conducted, employing the blood agar diffusion method against Streptococcus mutans. The physical evaluation of the clove oil edible film showed almost the same physical properties as the comparison (GF). Clove oil edible film test results revealed the greatest inhibition at $F_{1}$ of $18.6 \mathrm{~mm} \pm 0.577, F_{2}$ of $22.3 \mathrm{~mm} \pm 2.081$, and $F_{3}$ of $25.3 \mathrm{~mm}$ \pm 1.527 . According to David and Stout, the inhibition activity of bacteria on $\mathrm{F}_{3}$ was categorized as a very strong group inhibition response. In addition, ANOVA test analysis results uncovered that the concentration of clove oil affected the inhibition of the Streptococcus mutans bacteria with a significance value of $0.000(p$ $<0.05$ ). Also, Duncan's test exhibited that each concentration of clove oil had a significant difference in the inhibition of Streptococcus mutans bacteria.

Keywords: antibacterial, edible film, eugenol, agar diffusion, clove oil

\section{INTRODUCTION}

Clove oil has secondary metabolites in the form of essential oil with the highest eugenol content so that it has biological activity as an antiseptic and analgesia in the treatment of teeth and mouth,

\section{Data of article}

Received : 28 Apr 2021

Reviewed : 23 July 2021

Accepted : 18 Aug 2021

\section{DOI}

10.18196/jfaps.v2i1.11640

Type of article:

Research

\footnotetext{
*Corresponding author, e-mail: nwida777@gmail.com
}

antifungal, antibacterial, antioxidant, and anticarcinogenic ${ }^{1}$. Clove oil can be isolated from the leaves (1-4\%), stems (5-10\%), and clove flowers (10-20\%). Previous research was about the bactericidal effect of clove oil on Streptococcus mutans and Streptococcus pyogenes bacteria, which 
were tested on mouthwash preparations at $0.5 \%, 0.75 \%$, and $1 \%$ clove oil concentrations. It was shown that there was no minimum bactericidal concentration $(\mathrm{MBC})$ ) at a concentration of $0.5 \%$, so it was concluded that it could inhibit bacterial growth (bacteriostatic). Meanwhile, at concentrations of $0.75 \%$ and $1 \%$, clove oil had an MBC value, so that it was denoted to have bacteria-killing activity (bactericidal)2.

Moreover, oral hygiene preparations that have been widely circulated are in the form of toothpaste, mouthwash, and edible film as mouth fresheners containing menthol. The edible film is a thin layer made of safefor-consumption materials and used as a wrapper to prevent the process of fat oxidation, organoleptic changes, microbial growth, or absorption of moisture. In addition, edible films function as a barrier against the mass transfer of solutes, as a carrier for additives, and improving the handling of food 3 . The formation of edible films can also prevent the evaporation of eugenol in clove oil since one of its functions is as a barrier to mass transfer. Many studies on edible films have been conducted, including the use of betel leaf extract as an anti-halitosis formulated in the form of edible films ${ }^{4}$ and areca seed extract edible films as antibacterial 5 .

On the other hand, Streptococcus mutans is a bacterium capable of attaching to the tooth surface that produces glucosyltransferase enzyme. These enzymes produce insoluble glucans in water and play a role in causing plaque and colonies on the tooth surface ${ }^{6}$. The growth of Streptococcus mutans must be inhibited so that it does not become pathogenic and cause caries by giving antibacterial agents. One way to prevent caries is to limit the plaque formation on the tooth surface, either by preventing its formation or regularly cleaning plaque. Plaque control can be done by mechanical and chemical cleaning of plaque containing antibacterial ingredients, suppressing Streptococcus mutans growth. Based on the description above, the formulation of clove oil in the form of edible film was carried out, which could prevent the evaporation of clove oil compared to the dosage form of toothpaste and mouthwash and tested its antibacterial activity against Streptococcus mutans.

\section{METHOD}

\section{Materials and Tools}

\section{Materials}

Clove oil (PT. Lansida), corn starch (Maizenaku), HPMC (Brataco), sorbitol (Brataco), Na-saccharin, mint oil, menthol (Brataco), sodium metabisulfite (Brataco), nipagin (Brataco), nipasol (Brataco), and aqua dest

Culture of Streptococcus mutans ATCC 31987, 70\% ethanol (Brataco), crystal violet solution, Lugol's solution, safarin solution, physiological $\mathrm{NaCl}$ solution (Widatra), Blood agar media, Comparative $\left(\mathrm{GF}^{\circledR}\right)$, and Dimethylsulfoxide (Merck).

\section{Tools}

The tools used were digital scale (Shimadzu), refrigerator (Panasonic), hot plate and magnetic stirrer (Boeco), oven (Memmert), desiccator, modified edible film printing equipment, caliper (Kenmaster), pH meter (Ohaus), Roche friabilator (Amtast CS-2), incubator (Memmert), LAF (Laminar Air Flow) (Robust), autoclave (Memmert), and micropipette (Soccorex). 


\section{Clove Oil (Syzygium aromaticum) Edible Film Formula}

The edible film formula used referred to the formula made by Harmely et al. (2014) because this formula gave good results in previous studies.

Table 1. Formula Edible Film

\begin{tabular}{lllll}
\hline \multicolumn{1}{c}{$\begin{array}{c}\text { Composition } \\
\text { (\%) }\end{array}$} & Fo & F1 & F2 & F3 \\
\hline Clove oil & 0 & 1 & 1.5 & 2 \\
Corn starch & 6 & 6 & 6 & 6 \\
HPMC & 4 & 4 & 4 & 4 \\
Sorbitol 70\% & 4 & 4 & 4 & 4 \\
Na Saccharin & 0.25 & 0.25 & 0.25 & 0.25 \\
Menthol & 0.1 & 0.1 & 0.1 & 0.1 \\
Candy Oil & 1 & 1 & 1 & 1 \\
Nipagin & 0.18 & 0.18 & 0.18 & 0.18 \\
Nipasol & 0.02 & 0.02 & 0.02 & 0.02 \\
Na & 0.02 & 0.02 & 0.02 & 0.02 \\
Metabisulfite & & & & \\
Distilled water & 100 & 100 & 100 & 100 \\
up to & & & & \\
\hline
\end{tabular}

Description:

$\mathrm{F}_{1}$ : Clove oil concentration of o\%

$F_{2}$ : Clove oil concentration of $1 \%$

$\mathrm{F}_{3}$ : Clove oil concentration of $1.5 \%$

$\mathrm{F}_{4}$ : Clove oil concentration of $2 \%$

Corn starch was dispersed into 20 parts of aqua dest, heated at $\pm 60^{\circ} \mathrm{C}$, and stirred until a clear gel was formed. HPMC was developed in distilled water, which had added sorbitol and sodium saccharin, and then was stirred at a temperature maintained at $\pm 60^{\circ} \mathrm{C}$. The two gels were mixed at a temperature of $\pm 60^{\circ} \mathrm{C}$ by adding other additives (nipagin, nipasol, menthol, mint oil, Na metabisulfite, and clove oil) at room temperature; the mixture was stirred homogeneously, then was poured and leveled on the mold ( $26 x$ $20 \mathrm{~cm}$ ). The preparation was dried in the oven at a temperature of $40-50^{\circ} \mathrm{C}$ for 24 hours. Then, the edible film formed was released from the mold and cut into pieces with $2.2 \times 3.2 \mathrm{~cm}$.

\section{Edible Film Evaluation}

\section{Organoleptic Examination}

The organoleptic examination included visual observations using the five senses on the edible film's shape, smell, taste, and color. This examination was carried out at room temperature $\left(15-30^{\circ} \mathrm{C}\right)^{7}$.

\section{Edible Film Friability Examination}

The friability of the edible film was carried out according to the friability test of the tablet, 8,9 utilizing a Roche Friabilator. First, 20 sheets of edible film free of dust $\left(W_{1}\right)$ were weighed, then put into the Roche Friabilator. The tool was run for four minutes with a rotation speed of $25 \mathrm{rpm}$. The 20 edible films were cleaned of dust and weighed again $\left(W_{2}\right)$. Edible film friability can be calculated by the formula:

Friability $=\frac{W 1-W 2}{W 1} \times 100 \%$

\section{Drying Shrinkage Examination}

The porcelain dish was dried in an oven at $105^{\circ} \mathrm{C}$ until a constant weight (A) was obtained. Edible film weighed $2 \mathrm{~g}$ in a porcelain dish (B), then dried in an oven for 2-5 hours until a constant weight was obtained (C). The drying shrinkage was then determined in percent by weight of the sample used ${ }^{10}$.

$\%$ Drying shrinkage $=\frac{(B-A)-(C-A)}{B-A} \times 100 \%$

\section{4. pH Examination}

This examination was performed using the Inolab pH meter. First, this instrument was calibrated employing a buffer of $\mathrm{pH}_{4}$ and $\mathrm{pH}$ 7. The electrodes were rinsed with distilled water and dried. The $\mathrm{pH}$ measurement of the clove oil edible film was carried out by dissolving $1 \mathrm{~g}$ of the edible film in distilled water up to $10 \mathrm{ml}$. The electrode was immersed in the 
container, and the number on the $\mathrm{pH}$ meter represented the $\mathrm{pH}$ value of the clove oil edible film. ${ }^{7}$

\section{Edible Film Thickness Examination ${ }^{11}$} The thickness of the edible film produced was measured utilizing a micrometer with an instrument accuracy of $1 \mathrm{~m}$. Measurements were made at five different places.

\section{Swelling Test}

The swelling test was carried out by inserting one sheet of edible film into a glass beaker, then expanded with $10 \mathrm{~mL}$ of distilled water. Then, it was determined how long it took the preparation to expand. ${ }^{12}$

\section{Antimicrobial Activity Test by Diffusion Method (Kirby Bauer Method)}

This method was used to determine the activity of antimicrobial agents. A plate containing an antimicrobial agent was placed on an agar medium on which microorganisms had been grown, which would diffuse into the agar medium. Then, it was incubated at $37^{\circ} \mathrm{C}$ for $18-24$ hours. The clear zone indicated the presence of inhibition of the growth of microorganisms on the surface of the agar medium $^{13}$.

\section{Clove Oil Antibacterial Activity Test}

\section{Sterilization of tools and materials}

The tools utilized were washed and dried before being sterilized. Some tools, such as Petri dishes, were wrapped in newspaper, while the mouthpieces, test tubes, and droppers were covered with cotton and then wrapped one by one with newspaper. All tools were sterilized in an autoclave at $121^{\circ} \mathrm{C}$ for 15 minutes. Laminar Air Flow was cleaned and then sprayed with $70 \%$ ethanol. After that, it was sterilized by turning on a UV lamp for five minutes.

\section{Making Blood Agar Media}

The media powder of blood agar base was weighed as much as 4 grams, then dissolved with $100 \mathrm{ml}$ of distilled water and heated to boiling while stirring. Then, it was sterilized by autoclave at $121^{\circ} \mathrm{C}$ for 15 minutes. The sterile media was cooled to a temperature of $45-50^{\circ} \mathrm{C}$. Then, $10 \mathrm{~mL}$ of fresh sheep blood was added and stirred until smooth. Then, it was poured into a petri dish and waited for it to solidify. Once frozen, the media was ready to use.

\section{Preparation of Test Microbial Suspension}

Bacterial colonies were suspended in sterile physiological $\mathrm{NaCl}$ solution in sterile test tubes and homogenized by the vortex. Then, the turbidity of the equivalent suspension was measured by standard turbidity UV-Vis Spectrophotometry. Thus, a suspension with a transmittance of $25 \%$ at a wavelength of $580 \mathrm{~nm}^{2}$ was obtained ${ }^{13}$.

\section{Clove Oil Antibacterial Activity Testing}

The sterilized blood agar medium was poured into a $\pm 20 \mathrm{~mL}$ petri dish. After the media solidified, a sterile cotton swab was dipped into the bacterial suspension and then smeared evenly over the media. Sterile disc paper that had been previously dripped with clove oil with concentrations of $1 \%, 1.5 \%, 2 \%$, and as a negative control dimethyl sulfoxide (DMSO) was taken using a $10 \mu \mathrm{L}$ micropipette. It was incubated for 24 hours at $37^{\circ} \mathrm{C}$. Then, it was observed for bacterial growth. The inhibition area was also measured, indicated by the appearance of a clear area around the disc utilizing a caliper. 


\section{Edible Film Antibacterial Activity Testing}

Blood agar media sterilized was poured into a petri dish as much as $\pm 20 \mathrm{~mL}$. After the media solidified, a $5 \mathrm{~mm}$ diameter film sheet was placed on the agar medium and then incubated at $37^{\circ} \mathrm{C}$ for \pm 24 hours. The growth of bacteria was observed, and the inhibition area diameter was measured, indicated by the presence of an area not overgrown by bacteria. Tests were carried out on $F_{1}, F_{2}$, F3 preparations. Fo was used as a negative control based on the edible film, while $\left(\mathrm{GF}^{\circledR}\right)$ was employed as a comparison $^{14}$.

\section{Data Analysis}

The data on the antibacterial activity of clove oil in edible film preparations were processed by one-way analysis of variation (ANOVA) utilizing the SPSS program. The results will be meaningful if the comparison of inhibition in each formula gives a real and meaningful difference.

\section{RESULTS AND DISCUSSION}

This study aimed to formulate a preparation of clove oil (Syzygium aromaticum) in the form of an edible film as a deodorizer and determine its antibacterial activity against Streptococcus mutans. Clove oil contains eugenol as much as $78-98 \%$. The substance is produced from the oil glands on the surface of the clove flower body. In addition, clove oil also contains eugenol acetate, caryophyllene, and other minor compounds, in small amounts ${ }^{15}$.

Edible clove oil film was made by casting method on a mold $(26 \times 20 \mathrm{~cm})$. The edible film formed was removed from the mold and cut into pieces with $2.2 \times 3.2 \mathrm{~cm}$ (Figure 1).

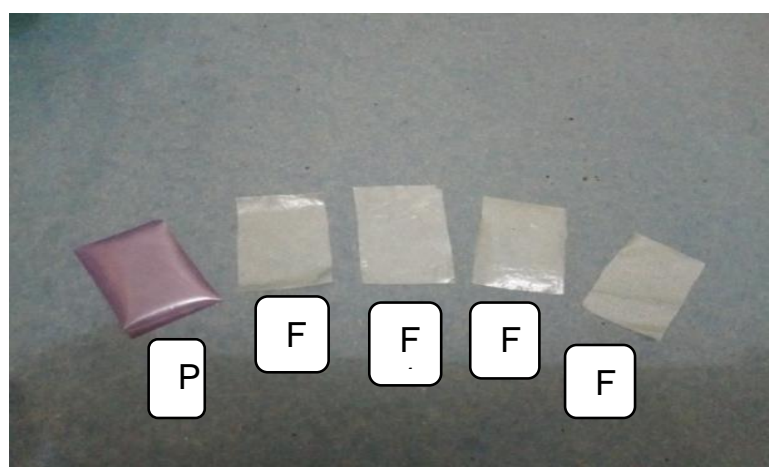

Figure 1. Preparation of clove oil edible film

Description:

$\mathrm{P}=$ Comparative Preparation Formula "GF"

Fo = Edible film base formula with $0 \%$ clove oil concentration

$\mathrm{F}_{1}=$ Edible film base formula with $1 \%$ clove oil concentration

$F_{2}=$ Edible film base formula with $1.5 \%$ clove oil concentration

$\mathrm{F}_{3}$ = Edible film base formula with $2 \%$ clove oil concentration

The edible clove oil film formed was evaluated for physical properties and activities against Streptococcus mutans. Evaluation of the clove oil edible film physical properties was then compared to the circulating physical properties (GF). 
Table 2. Evaluation Results of Clove Oil Edible Film

\begin{tabular}{cccccc}
\hline Evaluation & \multicolumn{5}{c}{ Observation } \\
\cline { 2 - 6 } & Fo & F1 & F2 & F3 & P \\
\hline Description & & & & & \\
-Shape & PLT & PLT & PLT & PLT & PLT \\
-Smell & KM & KMmc & KMmc & KMmc & KM \\
-Taste & Mm & MAPm & MAPm & MAPm & Mm \\
-Color & PT & PT & PT & PT & U \\
\hline Friability (\%) & 0.98 & 0.94 & 1.02 & 1.17 & 1.06 \\
& \pm 0.004 & \pm 0.004 & \pm 0.003 & \pm 0.007 & \pm 0.006 \\
\hline Drying shrinkage (\%) & 13.91 & 13.23 & 12.98 & 12.69 & 14.32 \\
& \pm 0.016 & \pm 0.013 & \pm 0.014 & \pm 0.013 & \pm 0.017 \\
\hline pH & 5.98 & 6.33 & 5.96 & 5.81 & 6.23 \\
& \pm 0.232 & \pm 0.156 & \pm 0.167 & \pm 0.143 & \pm 0.186 \\
\hline Thickness (mm) & 0.035 & 0.0392 & 0.044 & 0.050 & 0.010 \\
& \pm 0.0037 & \pm 0.0037 & \pm 0.0038 & \pm 0.0060 & \pm 0 \\
\hline Swelling test (second) & & & & & \\
& 08.48 & 10.31 & 12.22 & 14.15 & 05.93 \\
\hline Antibacterial activity & 10 & 18.6 & 22.3 & 25.3 & 10.5 \\
(mm) & \pm 0.5 & \pm 0.577 & \pm 2.081 & \pm 1.527 & \pm 0.5 \\
\hline
\end{tabular}

\section{Description}

PLT : Thin layer solid

KM : Typical mint

KMmc : Typical mint clove oil

The organoleptic examination of the clove oil edible film was carried out for six weeks. Every week, the organoleptic examination results of edible films showed no change in shape, smell, taste, and color. It indicates that the edible film preparation was stable during storage. In addition, the friability examination of edible films utilizing the "Roche Friabilator" friability test equipment did not appear to have changed shape or broken the edible film during the test. However, there was a reduction in the dosage weight caused by the edible film experiencing friction during testing. The $\%$ friability test results of the edible film also revealed that the \% friability of edible film $\mathrm{F}_{3}(1.17 \%)$ was higher than the comparison (1.06\%). This friability test describes the resistance of the preparation surface to the friction experienced during packaging, shipping, and storage. ${ }^{16}$
Mm : Refreshing sweet

MAPm : Sweet but a bit refreshing bitter

PT : Transparent white

U : Purple

The results of the edible film drying shrinkage examination uncovered that the highest drying shrinkage was shown in the formula Fo, which was $13.91 \%$, whereas the lowest was displayed in the comparison preparation, which was $12.69 \%$. Meanwhile, according to previous research, the percentage of good drying shrinkage for edible films was less than $9.29 \% .{ }^{17}$

Moreover, the $\mathrm{pH}$ evaluation of the edible film was performed for six weeks. The test results exposed that the $\mathrm{pH}$ changed every week but still met the physiological $\mathrm{pH}$ range of the mouth. Weekly changes in $\mathrm{pH}$ values might be caused by environmental factors, such as temperature, storage, and the sensitivity of the $\mathrm{pH}$ meter. The $\mathrm{pH}$ value of the resulting edible film must be in the $\mathrm{pH}$ range of the oral cavity, which ranges from 5.5 to $7.918^{18}$, so as not to 
irritate the oral mucosa when the preparation is consumed.

Next, the thickness of the edible film was examined employing a screw micrometer with an accuracy of $0.01 \mathrm{~mm}$ at five different places, and the results were then averaged. The thickness difference occurred due to clove oil concentration differences in each preparation, where $\mathrm{F}_{3}$ was the thickest compared to $F_{1}, F_{2}$, and Fo. The measuring results of the edible film thickness in all formulas met the requirements of a good thickness of the edible film, which was $<0.25 \mathrm{~mm}$. ${ }^{19}$ This thickness test was carried out to see that the edible film produced is thin but not easily torn, which is an indicator of uniformity and quality control of the edible film.

Further, in the swelling test, the mean swelling time results of the edible film were obtained. The measurement results disclosed that $F_{1}, F_{2}$, and $F_{3}$ required a longer time for the edible film to swell because it contained clove oil, which is difficult to dissolve in water with different concentrations. It is suspected that the mechanism of film destruction is through swelling and wicking mechanisms. The swelling process is that after the film is in contact with water, water penetration occurs due to capillarization (wicking) so that the film swells. Meanwhile, the wicking mechanism is the presence of water drawn by the disintegrant, where water will penetrate the film pores. As a result, the bonds between the particles become weak, and the film swells. ${ }^{11}$

Furthermore, the antibacterial activity testing of clove oil edible film against Streptococcus mutans bacteria was conducted using the agar diffusion method. This method is most commonly used to determine the activity of the test material against bacteria. The 24-hour incubation was carried out to give time for bacteria to multiply rapidly and carry out metabolic activities. The results showed that after 24 hours of incubation, all clove oil groups' concentrations could inhibit the bacteria Streptococcus mutans growth. The higher the concentration, the higher the zone of inhibition. It aligns with Pelczer and Chan's opinion that the higher the concentration of an antibacterial agent, the stronger the antibacterial activity. ${ }^{20}$

In this study, the test bacteria were suspended in a $0.9 \%$ physiological $\mathrm{NaCl}$ solution because the physiological $\mathrm{NaCl}$ solution was an isotonic environment for the test bacteria. The suspension was homogenized by vortex, and the turbidity was measured utilizing a UV-Vis spectrophotometer with a wavelength of $580 \mathrm{~nm}$ and transmitter $25 \%$, describing the optimal cell density for antibacterial activity testing. ${ }^{13}$

From the antibacterial activity test analysis, homogeneous and normal data were obtained, which showed that the data obtained were parametric, followed by one-way ANOVA statistics utilizing SPSS 16 and Duncan's test. The results of the one-way ANOVA statistical test revealed the $P$-value $(<0.005)$. It signifies a significant difference between all formulas. The difference in the concentration of clove oil at a $2 \%$ concentration did not show a significant difference with a $1.5 \%$ concentration but showed greater inhibition at a $2 \%$ concentration. In the edible film preparation, between the comparisons of the $\mathrm{GF}^{\circledR}$ edible film, a significant difference was shown with the edible film preparation in varying concentrations. However, on $1.5 \%$ clove oil edible film, it did not show a significant difference with ${ }_{1} \%$ and $2 \%$ edible film, but $2 \%$ clove oil 
edible film had greater antibacterial inhibition.

Based on the response table of bacterial growth inhibition according to Davis and Stout, the inhibition classification was divided into four categories: very strong $=$ $20 \mathrm{~mm}$, strong $=10-20 \mathrm{~mm}$, moderate $=5^{-}$ $10 \mathrm{~mm}$, and weak $=5 \mathrm{~mm}$. From the results obtained for each clove oil edible film formula, $F_{1}=18.6 \mathrm{~mm}, F_{2}=22.3 \mathrm{~mm}$, and $\mathrm{F}_{3}=25.3 \mathrm{~mm}$. It was categorized into a very strong bacterial growth inhibition response. According to a study, ${ }^{21}$ factors that affect the size of the inhibition zone include the organism sensitivity, the culture medium, the incubation conditions, and the rate of agar diffusion. Meanwhile, the factors that influence the rate of agar diffusion consist of the microorganism concentration, the medium composition, the incubation temperature, the incubation time, and the $\mathrm{pH}$ value of the medium. In this regard, some antibacterials work well under acidic conditions and others under alkaline conditions.

\section{CONCLUSION}

Clove oil with a concentration of $1 \%\left(\mathrm{~F}_{1}\right)$, $1.5 \%\left(F_{2}\right)$, and $2 \%\left(F_{3}\right)$ can be formulated in the form of edible film. From the physical evaluation results, almost the same results as the comparison of $\mathrm{GF}^{\circledR}$ in the form of edible film containing menthol were obtained. In addition, the antibacterial activity test results showed significant differences between $F_{1}, F_{2}$, and $\mathrm{F}_{3}$. Of the three formulas containing clove oil, $F_{3}$ gave the greatest inhibitory power of $25.3 \mathrm{~mm}(p<0.05)$ and was included in the very strong bacterial growth inhibition response.

\section{REFERENCES}

1. Prianto, H., Retnowati, R., Juswono, U.P. Isolasi dan Karakterisasi dari Minyak Bungan Cengkeh (Syzigium aromaticum) Kering Hasil Distilasi Uap. J Ilmu Kimia Univ. Brawijaya. 2013;1(2):269-75.

2. Riyadi, E. Efek Bakterisid dari Berbagai Konsentrasi Minyak Cengkeh dalam Sediaan Obat Kumur dengan Tween 8o Sebagai Surfaktan terhadap Streptococcus Mutans dan Streptococcus Pyogenes. Universitas Katalik Widya Mandala Surabaya; 2010.

3. Krochta, J. Control of Mass Transfer in Foods with Edible Coating and Film. New York: Elsevier Sci, Publ; 1992.

4. Arifin, M.F., Hidayati, LN., Syarmalina, S., Rensy, R. Formulasi Edible Film Ekstrak Daun Sirih (Piper betle L.) sebagai Antihalitosis. J Ilmu Kefarmasian Indones. 2010;8(1): 6168.

5. Ningsih, W. Formulasi dan Uji Efektivitas Antibakteri Edible Film Ekstrak Biji Pinang (Areca catechu Linn). JIFFK J Ilmu Farm dan Farm Klin. $\quad 2018 ; \quad$ 15(2): 71. http://dx.doi.org/10.31942/jiffk.v15i2. 2569

6. Pratiwi, R. Perbedaan daya hambat terhadap Streptococcus mutans dari beberapa pasta gigi yang mengandung herbal (The difference of inhibition zones toward Streptococcus mutans among several herbal toothpaste). Dent J (Majalah Kedokt Gigi). 2005; 38(2): 64 . 
7. Depkes. Farmakope Indonesia. Edisi III. Jakarta; 1979.

8. Voigt, R., Noerono, S. Buku pelajaran teknologi farmasi. Ed.3, peny. Yogyakarta: Gadjah Mada University Press; 1994.

9. Harmely, F., Deviarny, C., Yenni, W.S. Formulasi dan Evaluasi Sediaan Edible Film dari Ekstrak Daun Kemangi (Ocimum americanum L.) sebagai Penyegar Mulut. J Sains Farm Klin. 2015;1(1):38.

10. Depkes. Farmakope Indonesia. Edisi IV. Jakarta; 1995.

11. Krochta, J. M., Baldwin, E. A. Nisperos-Carriedo, M. Edible coatings and films to improve food quality. New York: Technomic Publishing Company; 1994.

12. Djaya, A. Halitosis: Nafas Tak Sedap. Jakarta: Dental Lintas Mediatama; 2000.

13. Jasril, J., Teruna, H.Y., Zamri, A., Alfatos, D., Yuslinda, E., Nurulita, Y. Sintesis dan Uji Antibakteri Senyawa Bromo Kalkon Piridin. J Natur Indones. 2013;14(3):172.

14. Amaliya, R. R., Dwi, W., Putri, R. Karakterisasi Edible Film Daripati Jagung dengan Penambahan Filtrat Kunyit Putih sebagai Antibakteri Characterization Edible Film of Corn Starch with The Addition of White Saffron Filtrateas Antibacterial. J Pangan dan Agroindustri. 2014;2(3):43-53.

15. Towaha, J. Manfaat Eugenol Cengkeh dalam berbagai Industri di Indonesia. Perspektif. 2012;11(2):323-77.

16. Leon, L., Lieberman, A. H., Kanig, J. L. Teori dan Praktek Farmasi Industri.
Edisi III. Jakarta: Universitas Indonesia; 1994.

17. Kavitha K, Rajendra MR. Design and Evaluation of Transdermal Films of Lornoxicam K . 2011;2(2):54-62.

18. Barman I, G UCP. Effects of Habitual Arecanut and Tobacco Chewing on Resting Salivary Flow Rate and $\mathrm{pH}$. Int J Oral Heal Med Reserach. 2015;2(1):13-8.

19. Susanto T, Budi S. Teknologi pengolahan hasil pertanian. Surabaya; 1994.

20. Jamaluddin $\mathrm{N}$, Pulungan $\mathrm{MH}$, Warsito. Uji Aktivitas Antibakteri Minyak Atsiri Jeruk Purut ( Citrus hystrix DC ) terhadap Klebsiella pneumoniae ATCC Antibacterial Activity Test of Kaffir Lime ( Citrus hystrix DC ) Essential Oil Against Klebsiella pneumoniae ATCC. J Teknol dan Manaj Agroindustri. 2017;6(2):61-66. https://doi.org/10.21776/ub.industria. 2017.006.02.1

21. Schlegel HG. Mikrobiologi umum. Yogyakarta: Gadjah Mada Univ. Press; 1994. 